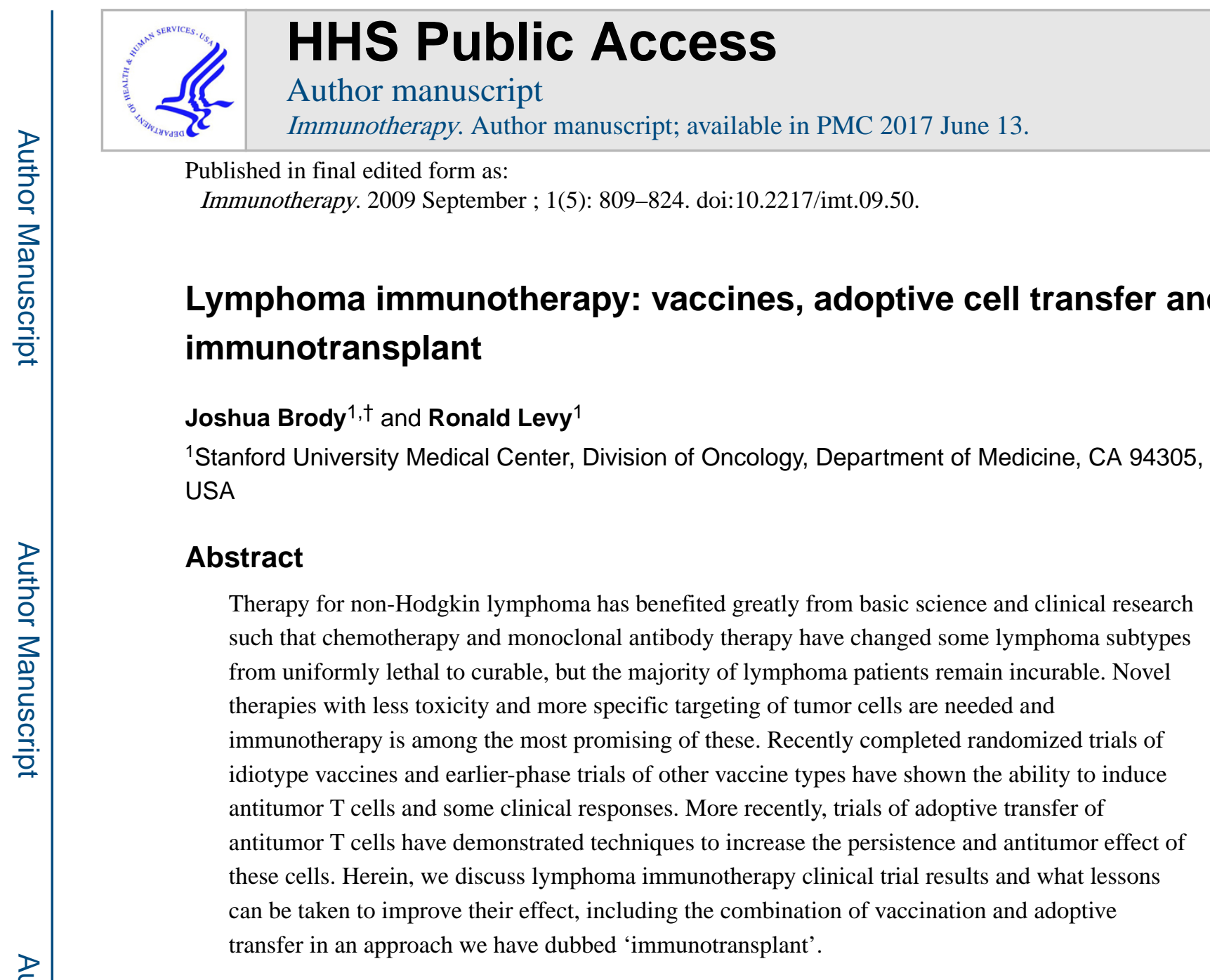

\title{
Keywords
}

adoptive transfer; chimeric antigen receptor; clinical trial; dendritic cell; idiotype immunotherapy; immunotransplant; lymphoma; vaccine

\begin{abstract}
Non-Hodgkin lymphoma (NHL) is the fifth most common cancer and the sixth most common cause of cancer deaths in the USA[201]. As the incidence of lymphoma is increasing more rapidly than that of any other cancer except melanoma[202] and has no known effective prevention, it may become an even more widespread problem in the near future, making the development of novel therapies an even more urgent priority. Patients with these diseases have benefited greatly from the past 50 years of basic science and
\end{abstract}

\footnotetext{
For reprint orders, please contact: reprints@ futuremedicine.com

${ }^{\dagger}$ Author for correspondence: Stanford University Medical Center, Division of Oncology, Department of Medicine, CA 94305, USA, Tel.: +1 650725 645, Fax: +1 650736 1454, josho@ stanford.edu.

Financial \& competing interests disclosure

The authors have no relevant affiliations or financial involvement with any organization or entity with a financial interest in or financial conflict with the subject matter or materials discussed in the manuscript. This includes employment, consultancies, honoraria, stock ownership or options, expert testimony, grants or patents received or pending, or royalties.

No writing assistance was utilized in the production of this manuscript.

Websites

201 Surveillance, epidemiology and end results. http://seer.cancer.gov/statfacts/html/nhl.html

202 Surveillance, epidemiology and end results - cancer statistics fact sheets. http://seer.cancer.gov/statfacts
} 
clinical research. The development of multiagent chemotherapy regimens, and more recently their combination with monoclonal antibody-based passive immunotherapies such as rituximab, have changed some lymphoma subtypes from uniformly lethal to curable. Still, the majority of lymphoma patients remain incurable and most patients ultimately die of their disease. Low-grade and mantle-cell lymphomas constitute the majority of the incurable subtypes [1] and novel therapies are needed for patients with these diseases. As these patients have frequently been treated with a series of increasingly toxic regimens, new approaches should be made safer by more specifically targeting tumor cells. An extremely elegant way to achieve such tumor-specificity would be to trigger patients' immune systems to target their own tumors. Currently, no such active tumor immunotherapies are approved for clinical use. Recently, the first Phase III idiotype (Id) -based vaccine trials have been completed, showing positive immunologic and clinical responses [2]. These results, along with objective responses seen in early-phase trials of both cell-based vaccines-which induce antitumor T cells - and T-cell adoptive transfer trials - which increase the persistence of these cells - suggest that immunotherapy will become part of standard lymphoma therapy in the near future.

There are several rationales for exploring lymphoma immunotherapies. The majority of standard cytotoxic therapies work primarily on actively dividing cancer cells, and their pharmacokinetics require that cell division occurs during their limited time-exposure to these agents. Increasing evidence of subpopulations of quiescent but amply lethal progenitors, such as 'cancer stem cells', suggests that such cytotoxic therapies will be insufficient to be curative for these cancer types [3]. Conversely, more rapidly dividing cancer cells have higher rates of developing both genetic and epigenetic changes, which may allow their evasion of standard therapies, but could still be susceptible to immunotherapeutic approaches that adapt to changing targets. Lymphomas in particular are ideally suited to immunotherapy. As $95 \%$ of lymphomas are derived from B lymphocytes, they, similar to normal B cells, are able to function as antigen-presenting cells (APCs) to stimuate antitumor T cells. While most other types of cancer express class I MHC molecules on their surface, B-cell lymphomas also express the class II MHC molecules, making them uniquely able to present their own tumor-associated antigens (TAAs) to both CD8 and CD4 T cells.

It is because of this broad array of cell types and their interactions that recent advances in the basic science of tumor immunology may now allow for translation into more effective therapies. Broadly, cell types can be either effector cells, such as T cells, NK cells and plasma cells, or APCs such as dendritic cells (DCs), B cells and tumor cells themselves. Importantly, both effector and presenting cells can be either stimulatory or inhibitory of tumor immunity and, in particular, a greater understanding has developed of the latter cell types, such as regulatory T cells (Tregs), plasmacytoid DCs (pDCs) and myeloid-derived suppressor cells (MDSCs). Recent advances include the description of novel stimulatory and inhibitory pathways for many of these cell types. Effector cell pathways include the T-cellstimulatory 'common $\gamma$-chain cytokines' such as IL-2, -7, -15 and -21, the T-cell costimulatory pathways CD28 and 4-1BB/CD137, and the T-cell inhibitory pathway CTLA-4. APC pathways include activating stimuli such as ligands of the TNF-receptor family member CD40 or of the Toll-like receptor (TLR) family, and inhibitory mediators such as indoleamine dioxygenase and PD-L1/B7-H1. Activation of stimulatory pathways 
and blockade of inhibitory pathways are all currently being translated into early-phase clinical trials, either alone or in conjunction with cancer vaccines.

Progress in tumor immunotherapy has been hindered by several obstacles, both practical and conceptual. There are two distinct approaches to immunotherapy: individualized and standardized. Individualized approaches require the manufacture of a customized product from each patient's tumor cells or the immune system of each patient. T-cell therapies, DC vaccines, Id vaccines and tumor-derived heat-shock protein vaccines are in this category and because of the logistics they are among the most difficult to study in large-scale clinical trials. By contrast, 'standardized' vaccines such as mixtures of allogeneic tumors and immunostimulants are logistically easier, but run the risk of not faithfully representing the antigens of the patient's tumor and of inducing autoimmunity. Both of these practical problems have held back the pace, scope and chance of success for vaccine clinical trials. Beyond these practical obstacles, conceptually, both tumor-produced immunosuppressive factors (e.g., VEGF, TGF- $\beta$ and IL-10) [4-7] and endogenous immune-regulatory mechanisms (e.g., Tregs, MDSCs and pDCs) [8-12] limit the power of the immune system to generate and effect antitumor immune responses.

\section{Vaccine clinical trials}

\section{Trial design considerations Treatment of high-burden versus minimal residual disease}

The obstacle of tumor-produced immunosuppressive factors has raised the question as to whether vaccines can ever induce antitumor immune responses in heavily tumor-burdened patients, or only in patients with minimal residual disease (MRD). With regards to humoral responses, there is some preclinical evidence of this [13], though it is difficult to demonstrate with standard ELISA-based methods because residual disease may 'soak up' antitumor antibodies, decreasing their serum levels. In preclinical models, we have evidence that vaccination in the setting of macroscopic tumor burden results in the induction of inferior T-cell-mediated immune responses [BRODY J, STANFORD UNIVERSITY MEDICAL CENTER, UNPUBLISHED DATA]. Clinically, in the largest vaccination trial reporting T-cell-mediated responses, Id-specific T-cell responses were observed in nine of 16 patients vaccinated in the setting of minimal or no residual disease, but in none of nine patients with macroscopic residual disease [14]. Although unresolved, this issue has been a primary concern in trial design and presents a dilemma; vaccinating patients with high disease burden may decrease the likelihood of clinical response, but vaccinating patients after cytoreductive therapy requires large-scale randomized trials to determine the added benefit of vaccination. In this setting, one conceivable way to demonstrate immunotherapeutic efficacy in lieu of randomized clinical response data is by using surrogate end points such as immune response data.

\section{Immune monitoring}

A central issue in trial design is the need for immune response monitoring after vaccination and correlation with clinical response. Study of immune responses may lead to an understanding of how vaccines work, and can yield immediate information regarding vaccine efficacy in the minimal disease setting when clinical response rates cannot be 
measured. Historically, measurements of humoral responses have been straightforward to perform and interpret. Pre-and post-vaccination sera can be banked and used for ELISA or flow cytometry-based measurements of serum antibody levels against tumor antigens or whole tumor cells and, thus, made reproducible. Consideration can be given to the significance of the particular isotype (e.g., $\operatorname{IgM}$ vs $\mathrm{IgG}$ ) and subclasses (e.g., $\operatorname{IgG}_{1} \mathrm{vs} \operatorname{IgG}_{2 \mathrm{a}}$ ), although these are reasonably well understood and agreed upon. Most importantly, the efficacy of antimicrobial vaccines is clearly correlated with humoral immune response measurements.

Conversely, despite the importance of T-cell responses in the clearance of tumors [15], and lymphoma in particular [16], measurements of T-cell-mediated immune responses have been difficult to reproduce and clinically validate. In contrast to humoral responses, there are many ways of measuring T-cell-mediated responses to vaccination, although it is unknown which will best correlate with clinical responses. These can be broadly categorized into measurement of antitumor $\mathrm{T}$ cells, proportion among peripheral blood $\mathrm{T}$ cells, or their ability on in vitro re-exposure to tumor antigens to: proliferate, produce cytokines, upregulate activation markers, lyse tumor cells.

Examples of the first category include fluorochrome-labeled tetramer conjugates of MHC molecules and tumor antigen peptide, which bind $\mathrm{T}$ cells specific for that peptide. The benefit of MHC-peptide tetramers are their great sensitivity in detecting antitumor T cells, although there are several drawbacks as well. These include the requirement to know the exact peptide being targeted, the suitability of a given tetramer reagent for only those patients of the same MHC type, and the lack of information regarding the functional state of the $\mathrm{T}$ cells identified [17]. The second category - measurement of patient T-cell proliferation in response to in vitro antigen re-exposure - was previously performed by measurement of ${ }^{3} \mathrm{H}$ thymidine incorporation; however, this approach does not allow discrimination of proliferating cell subsets and it is known that both effector and Tregs can proliferate in response to antigen. Newer methods, such as flow cytometric measurement of cellincorporated dye dilution (e.g., carboxyfluorescein succinimidyl ester [CFSE]) can measure proliferation with concomitant assessment of cell subtype to address this problem. The third category of assay measures patients' $\mathrm{T}$ cells production of cytokine -most frequently IFN- $\gamma$ upon tumor exposure and are among the most widely used assays in recent vaccine trials. Previously, cytokines could be measured in the supernatant of lymphocyte-tumor cocultures using ELISA, although the prevailing method in recent trials has been the ELISPOT assay, which yields a sensitive quantification of the proportion of tumor-induced cytokineproducing cells $[17,18]$. Unfortunately, ELISPOT assays have been difficult to reproduce between laboratories and also cannot determine which of the many T-cell subtypes are producing the measured cytokine $[19,20]$. An alternate approach here is flow-cytometric intracellular cytokine staining, which can simultaneously assess cell subtype and cytokine production. This approach has the additional benefit that it can allow measurement of multiple cytokines within a single cell, thus increasing the confidence that the measured cell truly demonstrates antitumor functionality. This latter approach can also be combined with the fourth category of assay using flow cytometric measurement of T-cell activation markers in response to tumor. Two of the more validated measurements here include the costimulatory molecule 4-1BB/CD137 [21] and the degranulation marker CD107 [22]. 
Finally, although approaches that directly measure tumor lysis such as ${ }^{51}$ chromium release assays have been beset by logistical difficulty and problems of high background, newer alternatives have examined replacing radioactive labeling with fluorogenic caspase substrates [23] or by measuring mediators of cytolysis such as perforin or granzymes [17].

Combinations of these approaches can improve the likelihood that measured responses are significant, but ultimately these need to be correlated to clinical outcomes. This field will advance greatly when vaccines yield significant clinical responses in the high-tumor-burden setting. In such trials, immune responses can be validated by correlation with clinical response. Those vaccines can then be optimized in small-scale trials in the (more favorable) minimal disease setting, where immune responses may be more robust. The first step must be a vaccine strategy with efficacy in the high tumor burden setting.

\section{Protein versus cell-based vaccines}

Cancer vaccines educate the immune system to recognize TAAs, although those antigens can be prespecified or unknown. In the latter case, whole tumor cells, or even whole tumors (which include cells of both the tumor and of the tumor microenvironment), can be made immunogenic in various ways, and the immune system is left the job of distinguishing between TAAs and self-antigens. Alternatively, a TAA can be made immunogenic by admixture with an immunostimulant or by conjugation to a carrier protein. Of this latter approach, the most thoroughly studied has been the Id moiety of the immunoglobulin protein expressed by all mature B-cell malignancies, particularly NHL.

\section{Protein vaccines}

\section{Idiotype vaccines}

B lymphocytes each express an immunoglobulin molecule on their surface, the variable region of which - referred to as the idiotype - results from a unique genetic recombination event. As clonal derivatives of a single progenitor, each lymphoma cell expresses the same Id, different than that of every other B cell, and thus a truly tumor-specific antigen. Since monoclonal antibodies directed against B-cell lymphoma idiotypic regions have demonstrated efficacy as a passive immunotherapy [24-26], it makes sense that Id vaccines inducing a polyclonal humoral immune response, should be at least as effective as the passive approach. Such vaccines have usually been produced by coupling of a tumor's fulllength heavy and light immunoglobulin chains to a carrier protein, such as keyhole limpet hemocyanin (KLH), and administration with an adjuvant, such as GM-CSF. The development, extensive preclinical and early-phase clinical evidence supporting Id vaccination have been well reviewed previously $[27,28]$.

Several early-phase trials have demonstrated that Id-KLH vaccines induce both measurable immunologic (humoral) and clinical responses [29-34] and have an excellent safety profile [35]. Although the majority of these studies vaccinated patients after cytoreductive therapy, some have vaccinated patients with measurable disease and have demonstrated mixed [36] or objective clinical responses [29] as a monotherapy. These encouraging results have prompted three randomized Phase III clinical trials of Id-KLH vaccination after an initial 
cytoreductive therapy. As of 2008, all three have informally reported final results on their primary end points (TABLE 1). Of these, the two larger studies, conducted by Genitope and Favrille, reported no statistical differences in progression-free survival or time to progression, respectively, although the former study demonstrated provocative data regarding the correlation of immune (humoral) and clinical responses [2]. Interestingly, the latter study demonstrated a significant (but similar) proportion of 'late' (more than 3 months after chemotherapy) improvements in clinical response. As seen in the Favrille trial, this may be even truer in the case of Rituxan ${ }^{\circledR}$, given its greater in vivo half-life. These data are a sobering reminder that continued benefit from standard therapies are common and are insufficient evidence of the benefit of a subsequent experimental therapy.

More recently, Biovest reported that its trial demonstrated a disease-free survival of 44.2 months for patients in the experimental arm versus 30.6 months in the control arm ( $\mathrm{p}=$ 0.045). This was remarkable given the less than $50 \%$ accrual secondary to early closure. An additional problem in interpreting these data is that the prespecified p-value for clinical significance was 0.01 (vs the commonly used 0.05 ). This trial is currently being reviewed by the US FDA and we will await the data's peer-reviewed publication to better understand its implications. If the data prove to be robust, it would be of great interest for its difference from the other two trials. Although there are a number of minor differences between the three trials - including Id synthesis methods - the most striking difference was the proportion of patients free of macroscopic disease (100 vs 10 and 8\%, respectively) as expected from the requirements for randomization in each trial. If these data are confirmed in future studies, it would strongly suggest that vaccination in the MRD state is significantly more powerful and could yield additional trials taking advantage of this insight.

If the clinical benefit of Id-KLH vaccination is confirmed, a number of improvements have already been considered that could make the approach even more practical and powerful. Preclinical and clinical data have shown that the power of Id vaccination can be increased in a number of ways, including: more effective ways of conjugating the Id protein to the KLH carrier [37], pulsing of Id-KLH onto autologous DCs [14], incorporation of Id into a cytokine-carrying liposome [38], and combined treatment with anti-CTLA4 monoclonal antibodies to lower the threshold of tumor-specific T-cell activation [39]. If, as suggested, the minimal disease state is shown to be important for the induction of clinically significant antitumor responses, a number of trials have already shown that vaccination can induce immune responses after higher-dose conditioning therapy [40] or even after myeloablative conditioning and stem cell transplant [41]. The practical difficulties of rapid, large-scale synthesis of individualized idiotype protein for each patient have been addressed in a number of studies, including production in plant cells $[42,43]$, production in a cell-free protein-expression system [44], or direct vaccination with Id-encoding DNA [45]. Whereas the aforementioned Phase III trials of 'first-generation' vaccines were hindered by limitations of cost, manufacturing capacity, and inability to make vaccine in time for all patients, it is conceivable that these advances could streamline future trials to more rapidly determine the optimal vaccination approach. 


\section{HSP96 vaccines}

An alternate, protein-based approach to vaccination has been the use of tumor-derived heatshock protein-peptide complexes such as HSP96. This class of proteins, by virtue of their function as molecular chaperones involved in protein-folding, become associated with a wide array of intracellular peptides, some of which may be TAAs suitable for MHC presentation. The greatest distinction from the Id approach is that the exact antigen(s) are not specified, but are hopefully selected for by the immune system. A number of preclinical studies [46] and clinical trials $[47,48]$ in other tumor types prompted an early-phase study of this approach for indolent lymphoma. In this study, 20 patients were accrued and there were no significant adverse events of vaccination, although the only evidence of clinical benefit were a number of patients with stable disease and one patient with a subclinical regression [49]. By combining this type of vaccine with additional adjuvants to induce a detectable immune response - as has been seen in trials of other tumor types [9] - it is possible that such a lymphoma vaccine could be made more powerful.

\section{Cell-based vaccines}

Although protein-based approaches have shown efficacy in infectious disease vaccines and in preclinical models of cancer vaccines, to function effectively they require processing and presentation by APCs. The possibility that APCs can be functionally impaired by prior therapies or by the cancer-bearing state suggests an alternative approach - the ex vivo production, antigenloading and activation of APCs, such as DCs. In addition to the DC-IdKLH study described, this has also been studied by pulsing DCs with tumor lysates from both B-cell [50] and T-cell [51] lymphomas - the latter approach demonstrating significant single-agent activity with four partial responses and one complete response in cutaneous disease (TABLE 2). There is now an ongoing clinical trial of a similar approach for the systemic (Sezary) stage of this disease (ClinicalTrials.gov Identifier: NCT00099593). More recently, an alternate approach of pulsing autologous DCs with apoptotic (heat-shocked and UV-irradiated) tumor cells was demonstrated by Di Nicola et al. to yield an impressive 33\% objective response rate with six (three partial and three complete) responses [52].

Another approach to circumvent the deficiency of functional APCs in the cancer-bearing host is made possible by the unique phenotype of B-lymphoma cells. Since lymphoma cells can -upon activation - express MHC class II and costimulatory molecules such as CD80 and CD86, it is possible to use lymphoma cells themselves as the tumor-antigen-bearing APCs. Although these cells are insufficiently immunogenic in their natural state, a number of immunostimulatory approaches to 'activate' these cells have been studied. One approach has been activation via the CD40 molecule either by admixture of tumor cells with CD40Lexpressing cells $[53,54]$ or by viral-induced CD40L expression on tumor cells themselves [55-57]. Another interesting approach has used autologous tumor cells treated with heatshock and UV irradiation (similar to Di Nicola et al.) combined with oxidation, which was posited to increase the cells' immunogenicity [58]. These studies have demonstrated feasibility and immune responses as well as a minority of clinical responses (TABLE 2). Compared with DC production, these latter approaches also decrease the amount of ex vivo culture time of the vaccine product from 7 days to 1 day. Avoiding DC production offers a 
drastic decrease in complexity and expense of the manufacturing process. Furthermore, it is possible that direct 'forced' antigen presentation on tumor cells, which may reflect more accurately the peptides presented by tumor cells themselves. Whether these activated lymphoma cells can be as effective as the 'professional APC' DCs is unknown, although the seemingly higher response rates amongst the $\mathrm{DC}$ trials raises that question.

Our group has considered an alternate approach - localized, low-dose radiation to a single site of lymphoma, followed by intratumoral injection of immunostimulatory $\mathrm{CpG}$ molecules at the same tumor site. $\mathrm{CpG}$ molecules - synthetic oligodeoxynucleotides enriched for hypomethylated CG repeats - bind to TLR9 found on both B-lymphoma cells as well as DCs. This approach allows both the tumor cells themselves, as well as the nearby professional APCs, to be activated and present tumor antigens, which was shown preclinically to induce significant tumor-specific CD8 T-cell responses and systemic antitumor immunity [59]. Recently, we have completed treatment of 15 patients with lowgrade lymphoma using this approach and have demonstrated both complete and partial responses, as well as the induction of tumor-specific CD8 T-cell responses [60]. The simplicity of this 'off-the-shelf' approach is that the immunostimulant produces the individualized vaccine in situ instead of ex vivo. As compared with protein-based, or even cell-based vaccinations, this 'whole-tumor' vaccination approach also offers a new possibility: vaccination against not only TAAs, but also antigens on cells in the tumor microenvironment. Such stromal cells are qualitatively different than tumor cells in their inability to mutate around selective immune pressure and may, thus, provide an even more sensitive target. Finally, it should be considered that this approach has a potential doserelated benefit compared with other strategies. Whereas whole-cell vaccine trials have used from $2 \times 10^{7}$ to as many as $3 \times 10^{9}$ cells per vaccine, the intratumoral approach in our patients with tumors ranging from 3 to $64 \mathrm{~cm}^{3}$ may have an effective APC dose of 10-100times higher than even the highest doses previously tested. These factors may contribute to the encouraging clinical results seen, including complete and partial responses (TABLE 2) in patients with high tumor burden who had already recurred after prior therapies.

\section{Adoptive transfer clinical trials}

As suggested, a large number of preclinical studies have demonstrated that the potency of cancer vaccines is inhibited by both tumor-produced factors (e.g., VEGF, IL-10 and TGF- $\beta$ ) and endogenous immunoregulatory obstacles (e.g., Tregs, MDSCs and pDCs). Although it is conceivable that tumor immunity could be suppressed at either the afferent limb (induction of an immune response) or the efferent limb (effector cell trafficking to, and elimination of, tumor cells), preclinical lymphoma models have shown the majority of immune-regulatory obstacles appear to interfere with the afferent limb [61]. Consistent with this, a number of groups have conceived of ways to 'skip' this step by infusing ex vivo-manufactured anticancer $\mathrm{T}$ cells and, in effect, proceeding directly to the efferent limb. In addition to bypassing those obstacles to the induction of immunity, this approach affords an opportunity to deal with endogenous immune regulatory obstacles; prior to T-cell infusion, patients can be treated with leukodepleting therapies to eliminate immunosuppressive cells and competition for limited amounts of T-cell activating cytokines, such as IL-7 and IL-15 [62]. This approach has proven to be critical to the success of tumor-infiltrating lymphocyte (TIL) 
transfer in the treatment of melanoma [63-65] and may also make adoptive transfer therapies for lymphoma sufficiently powerful.

As with cancer vaccines, the first problem in cell transfer therapy is the determination of a TAA target. This is considerably more complex for T-cell therapies than for passive immunotherapy with antibodies. Whereas antibodies have historically been developed in the 'biological factory' of a rodent immune system then genetically fine-tuned to remove their xenoantigenicity, no such approach has existed for T-cell development, hence their only more recent implementation. There are, however, several potential advantages to T-cell transfer as compared with antibodies. Foremost, $\mathrm{T}$ cells can target intra-cellular proteins, so long as they have some immunogenic peptide component presented on surface MHC molecules. As many conceivable tumor-specific molecules, such as kinases, antiapoptotic factors, and transcription factors may not otherwise be expressed on the cell surface, $\mathrm{T}$ cells are the only immunotherapeutic way to target these molecules. In addition, whereas many antibodies used for cancer therapy require the recruitment of additional effector cells (e.g., NK cells), which may, themselves be suppressed by cancer [66], transferred T cells incorporate both the targeting and effector aspects in a single unit, whose function can be assessed a priori.

\section{Nonspecific cell-transfer trials}

The potential of T-cell transfer therapies for lymphoma was considered even prior to the technical proficiency to target a specific antigen, based partly on successes achieved in allogeneic stem cell transplantation and donor lymphocyte infusions for leukemias such as chronic myeloid leukemia $[67,68]$ and even some lymphomas $[69,70]$. As these therapies are only feasible for a minority of lymphoma patients, we will focus herein on autologous cell therapies.

After initial clinical successes of IL-2 in the 1980s in treating melanoma and kidney cancer, it was considered that the dose limitations of systemic IL-2 administration could be avoided by brief (48-120 h) ex vivo exposure of autologous lymphocytes cells to higher concentrations than could be used in vivo. Several groups studied this approach of 'lymphokine-activated killer' (LAK) cells - which are generally a mixture of T and NK cells - reinfused into patients along with continued systemic IL-2 therapy. These approaches have been studied both as a monotherapy for lymphoma [71], and because of their high proportion of NK cells, in combination with rituximab in otherwise rituximab-refractory patients (TABLE 3) [72]. In support of that rationale, that study did report two partial remissions out of ten patients previously unresponsive to rituximab alone. In addition, to take advantage of the setting of MRD, these therapies have been studied in the postautologous transplant setting [73,74]. Generally, these trials have demonstrated feasibility and safety of the approach, but no clear single-agent clinical benefit.

More recently, the consideration that unimodal (IL-2) activation might not be as effective as multimodal activation, an alternate approach of culturing peripheral blood lymphocytes with a combination of IL-2, IFN- $\gamma$ and anti-CD3 antibody (for 21 days) has been investigated in patients with both Hodgkin's lymphoma and NHLs. These 'cytokine-induced killer' (CIK) cells are greatly enriched for CD8 T cells and a distinct population of $\mathrm{CD}^{+}{ }^{+} \mathrm{CD} 56^{+}$, which 
demonstrate marked in vitro cytotoxicity. The demonstration of patients with partial responses and prolonged stable disease in a highly pretreated (relapsed after autologous transplant) cohort, suggests some single-agent activity of this approach [75].

An early observation that has motivated more recent cell-transfer therapy research was that in vivo persistence of the transferred cells has been difficult to measure, and when it was measured has usually shown to be quite poor. One approach to overcome this problem has been to activate the transferred cells with both signal 1 (via the T-cell receptor (TCR)-CD3 complex) as well as signal 2 (via members of the costimulatory family of receptors typified by CD28); the latter signal being necessary to prevent T-cell activation-induced apoptosis. Several recent studies have used T cells expanded ex vivo with anti-CD3/anti-CD28 beads. In support of the hypothesis, a recent trial demonstrated a persistent improvement in T-cell function in postautologous transplant lymphoma patients, suggesting persistence of the transferred cells [76]. This approach has also been combined with ex vivo Treg depletion, demonstrating similar results using a nonmyeloablative conditioning regimen [77]. The benefit of including the CD28 coactivation signal is significant for both the transfer of $\mathrm{T}$ cells as well as that of chimeric antigen-receptor (CAR) cells as discussed later.

\section{Specific-selected T-cell transfer trials}

To increase the specificity, and hopefully the potency, of the transferred cells, a number of groups have attempted ex vivo enrichment and selection for T cells targeting particular antigens. One set of antigens that has been targeted exploits the association of Epstein-Barr virus (EBV) with several types of lymphoma, by using EBV-transformed autologous B cells as 'feeder cells' to expand patient T cells ex vivo (in some cases in combination with IL-2, allogeneic EBV-transformed cells and anti-CD3 antibody). An early report of this approach in $\mathrm{EBV}^{+}$Hodgkin lymphoma patients by Bollard et al. included gene-marked $\mathrm{T}$ cells (using an antibiotic-resistance gene) that could be tracked after transfer and was able to demonstrate in vivo proliferation of the transferred cells as well as their trafficking to tumor sites and persistence for up to 1 year in vivo (TABLE 3) [78]. Later, this group was able to show that by targeting only those EBV-related antigens which are highly expressed on EBVassociated tumors (e.g., the LMP2 protein) as opposed to the larger number of viral proteins expressed on in vitro EBV-transformed cells, that the transfer of $\mathrm{T}$ cells was sufficiently powerful to induce objective responses in five of six patients with active HL or NHL, four of which were complete responses [79]. A smaller study by Cho et al. was able to replicate this approach using both autologous or allogeneic, ex vivo EBV-primed T cells when treating patients with NK/T cell lymphomas [80].

Although the opportunity to target viral antigens may not exist in all lymphomas, this proof of principle for targeted T-cell therapies is quite encouraging and may even have applications for EBV-associated solid tumors, such as nasopharyngeal carcinoma, for which trials are currently ongoing (ClinicalTrials.gov Identifier: NCT00608257). In addition, the observation that the transferred $\mathrm{T}$ cells in these trials could be gene modified (with an antibiotic-resistance gene) with high efficiency and without losing function or being themselves targeted for their xenoantigens is very encouraging for the possibility of other types of genetically engineered T-cell-based therapies. As discussed above, the additional 
benefit of leukodepletion prior to T-cell transfer could make this approach even more powerful, and a novel, CD45 antibody-based leukodepletion regimen is currently being studied in conjunction with this therapy (ClinicalTrials.gov Identifier: NCT00608478).

\section{Specific-engineered T-cell transfer trials}

As lymphomas have a long history of being classified by their phenotype of surface molecules, and because of the difficulties described in determining potential intracellular TAAs, recent studies have explored genetically engineering $\mathrm{T}$ cells to recognize surface antigens without the context of MHC presentation. Since such strategies use genetically engineered receptors consisting of a single-chain variable fragment ( $\mathrm{scFv}$ ), an immunoglobulin and the intracellular portions of the CD3 $\delta$ chain (the signaling portion of the TCR), these constructs have been referred to alternately as CARs or 'T-bodies'. These genetic constructs are either lentivirally transduced or electroporated into autologous peripheral blood T cells, then directly reinfused, or selected, expanded ex vivo and then reinfused. Although this strategy is similar to passive immunotherapy with antibodies or tumor-specific T-cell transfer, by incorporating different signaling apparatus, it can 'guarantee' the effector cell receives sufficient stimulation and costimulation when encountering target cells (FIGURE 1).

After encouraging trials using CARs to treat chronic viral infections [81], CD19-or CD20targeted CARs have shown in vitro-specific lysis of a variety of lymphoma subtypes [82], activity in human lymphoma-bearing mouse xenograft models [83], and safety in earlyphase clinical trials in other tumor types [84]. These have prompted a number of recent trials for lymphoma patients, the first of which, using the simpler construct of only scFv plus CD38, have been published [85] or presented [86], demonstrating safety, feasibility, moderate in vivo persistence and some clinical activity (TABLE 3 ).

Studies of these first-generation CARs have already brought about numerous modifications to the technology, which appear to improve their likelihood for success. These include standardized protocols for high efficiency and GMP quality production using electoporationtransfected [87] or virally transduced [88] peripheral blood T cells. In addition, to specifically target cytokine-receptor-bearing tumor cells without the need for constructing a $\mathrm{scFv}$ extracellular domain, Kahlon et al. described the use of cytokine-CD3 $\delta$ fusion construct CARs (called 'zetakines') [89] which have shown antitumor activity in xenograft models of IL-13R $\mathrm{R}^{+}$malignant gliomas. In another related approach, the goal of forcing $\mathrm{T}$ cells to engage lymphoma cells has been accomplished without the need for ex vivo manipulation using a bispecific monoclonal antibody (or 'BiTE') targeting both CD3 and CD19, and this has already demonstrated clinical activity inducing partial and complete responses [90].

As a primary obstacle for all of these adoptive transfer approaches has been maintaining the persistence of the transferred cells in vivo, a number of strategies are being explored to improve the survival and activation of CARs in vivo. These strategies can work either at the level of the CAR genetic construct, cells into which the CAR is inserted, or the patient into which the CAR cells are infused. At the CAR level, the addition of costimulatory signaling domains in tandem with the primary $\mathrm{CD} 3 \S$ chain signaling domain - such as those from 
CD28 [91-93] or 4-1BB/CD137 [94,95] -have been shown to enhance persistence and antitumor activity of the CARs in vivo. At the cell level, a recently described approach has been to exploit the endogenous 'bystander' TCRs. As anti-EBV-targeted T cells were previously shown to have significant persistence in vivo, instead of transducing a CAR construct into all $\mathrm{T}$ cells, investigators used the previously described EBV-specific T-cell clones and observed enhanced persistence of these cells in EBV-infected patients [96]. In the future, another approach at the cell level will probably be to enrich the transduced $\mathrm{T}$ cells for subsets with an innate capacity for in vivo persistence, such as central memory T cells [97]. At the recipient level, it has already been seen that patients with lower disease burden have greater persistence of CARs [84] and that concurrent administration of IL-2 can increase their persistence from weeks to months [85]. In addition, ongoing studies are exploring the above discussed possibility of using leukodepleting conditioning regimens prior to T-cell transfer. These have included cyclophosphamide-[86] and/or fludarabine-based regimens (ClinicalTrials.gov Identifier: NCT00182650) and have already given some indications of improved efficacy [SADELAIN M, PERS. COMM.].

While initial data appear promising for the possible utility of T-cell-based therapies to treat lymphoma, there are a number of inherent obstacles. First, the potential for recipients to mount immune responses against reinfused genetically modified $\mathrm{T}$ cells as has been observed in prior trials of genetically modified $\mathrm{T}$ cells $[98,99]$ and the recently published CAR trial [85] should be expected and measured. Possibly, the ongoing studies of leukodepleting conditioning prior to infusion will - at least transiently - mitigate against this problem. Another key limitation of these highly targeted T-cell transfer approaches is their potential to select for 'escapee' tumor variants. In contrast to the TIL transfer therapy, which has shown remarkable efficacy in treating melanoma, these latter therapies are inherently restricted to a single or a few antigens, some of which may be expendable to the tumor cells' survival. If the advantages of T-cell transfer therapies - their capacity to actively migrate to sites of lymphoma, proliferate in vivo and take advantage of the leukodepleting effects of standard therapies - could be combined with the multitargeted, adaptive immunity induced by cancer vaccines, it is possible that they could be made more powerful.

\section{Conclusion}

The clinical trials reviewed in this article demonstrate the feasibility and safety of the wide array of immunotherapies studied for lymphoma. Early-phase studies of vaccines have shown that they can induce antitumor immune responses and have some efficacy as 'singleagent' therapies. Advances in this field include approaches such as in situ vaccination, which should be sufficiently practical to easily translate into larger scale trials. Clinical and preclinical studies show that vaccination in the MRD setting could have greater efficacy, although this approach comes with the need for large, randomized studies to prove the benefit of vaccination. Two such Phase III studies have been unable to demonstrate the benefit of Id vaccines; while preliminary data of a third study appear positive, these will require peer review. Apart from clinical benefit, it is clear that certain vaccine types are more effective than others in inducing an antitumor T-cell-mediated immune response. 
The alternate approach of adoptively transferring antitumor $\mathrm{T}$ cells produced ex vivo has also been shown to be feasible and safe. For certain lymphoma subtypes with well-defined tumor antigens (such as EBV-related tumors), early-phase trials have shown significant antitumor activity. Other trials have demonstrated techniques that can be used to increase the persistence and antitumor activity of transferred cells. One such approach - lymphodepletion prior to cell transfer - has been shown to be very effective, as has been shown for adoptive transfer of antimelanoma $T$ cells. Hopefully, this broad range of novel immunotherapies will be as transformative to the care of lymphoma patients over the upcoming decade as the advent of antibody therapy has been over the past decade.

\section{Future perspective: immunotransplant}

The possibility of exploiting the power of transferred $\mathrm{T}$ cells together with the flexibility of the adaptive immune response has already been investigated for infectious disease and shown to be effective. In a randomized study of a varicella-zoster vaccination for lymphoma patients undergoing hematopoietic stem cell transplantation, only pretransplant vaccination followed by post-transplant booster vaccinations were able to induce superior CD4 T-cell varicella-specific immune responses and a threefold reduction in the risk of zoster [100]. A remarkable observation from that study was the persistence of CD4 T cells specific for varicella for at least 1 year after transplant - a recurring theme in the transfer of $T$ cells into the lymphodepleted recipient. A later, randomized study of pneumococcal vaccination preand post-transplant demonstrated similar findings, demonstrating specifically that pretransplant vaccination resulted in higher antibody responses to most serotypes included in the vaccine [101]. Building on this work, Rapoport et al. used a four-arm randomization using the same pneumococcal vaccine and demonstrated a synergistic benefit in antipneumococcal $\mathrm{T}$ cells by combining pre-and post-transplant vaccinations and adoptive transfer of vaccine-primed lymphocytes [102].

This 'immunotransplant' approach - using the transfer of vaccine-primed lymphocytes into the post-transplant recipient has been extrapolated to the study of antitumor immunity in a number of preclinical studies. Borrello et al. demonstrated in a murine B-cell lymphoma model that a tumor vaccine was actually more effective in the posttransplant setting and that transfer of tumor-specific T cells induced their selective clonal expansion [103]. Other groups have also demonstrated the increased efficacy of post-transplant vaccination [104] and of transfer of tumor-specific T cells into the leukodepleted recipient [105]. Recently, we have published our initial data on immunotransplant, transferring lymphocytes from donor mice vaccinated with an intratumoral CpG-based vaccine and recipient mice receiving myeloablative irradiation and syngeneic bone marrow transplant. We demonstrated a marked increase in tumor-specific memory CD8 T cells, CD8 T-cell-dependent tumor protection, and cure of mice with established tumors as large as $8000 \mathrm{~mm}$ [106]. In contrast to transfer of TILs or CARs, transfer of vaccine-primed T cells introduces the problem of transferring Tregs along with tumor-specific T cells. However, our model demonstrated that upon transfer into the lymphodepleted recipient, tumor-specific memory $\mathrm{T}$ cells proliferate selectively and skew the Teffector:Tregs ratio in their favor (FIGURE 2). More recent data have demonstrated that the increase in tumor-specific immunity extends to multiple tumor types, vaccination strategies and mouse strains. However, we have also observed that certain 
vaccine types are only moderately enhanced by immunotransplant whereas others are drastically enhanced [Brody J, Stanford University Medical Center, Unpublished data]. Though, no clear rule distinguishing which vaccines can be improved using this approach, our initial data suggest that cell-based vaccines have had greater success than protein-based vaccines. Certainly, a better understanding of which vaccination strategies can be made more powerful using this approach would allow their effective translation into clinical trials. In fact, after initial clinical success transferring TILs into lymphodepleted melanoma patients, Powell et al. studied melanoma patients treated with peptide-based vaccines followed by autologous reinfusion of vaccine-primed lymphocytes after lymphodepletion and observed no clear benefit. This would be consistent with our preclinical findings and confirms the need for a greater preclinical understanding of which vaccine types are appropriate for clinical trials of immunotransplant. The improvement of current vaccine and adoptive cell transfer therapies, either by immunotransplant, or by the above-described, preclinically proven optimization strategies, should yield early-phase trials with a high promise for clinical success.

\section{Bibliography}

Papers of special note have been highlighted as:

of interest

a of considerable interest

1. The Non-Hodgkin's Lymphoma Classification Project. A clinical evaluation of the International Lymphoma Study Group classification of non-Hodgkin's lymphoma. Blood. 1997; 89(11):39093918. [PubMed: 9166827]

2. Levy RR, Ganjoo MK, Leonard J, Vose J, Denney D. Results of a Phase III trial evaluating safety and efficacy of specific immunotherapy, recombinant idiotype (Id) conjugated to KLH (Id-KLH) with GM-CSF, compared with non-specific immunotherapy, KLH with GM-CSF, in patients with follicular non-Hodgkin's lymphoma (fNHL). AA CR Meeting Abstracts. 2008

3. Huff CA, Matsui W, Smith BD, Jones RJ. The paradox of response and survival in cancer therapeutics. Blood. 2006; 107(2):431-434. [PubMed: 16150939]

4. Yang L, Carbone DP. Tumor-host immune interactions and dendritic cell dysfunction. Adv Cancer Res. 2004; 92:13-27. [PubMed: 15530555]

5. Gabrilovich DI, Chen HL, Girgis KR, et al. Production of vascular endothelial growth factor by human tumors inhibits the functional maturation of dendritic cells. Nat Med. 1996; 2(10):10961103. [PubMed: 8837607]

6. Loeffler CM, Smyth MJ, Longo DL, et al. Immunoregulation in cancer-bearing hosts. Downregulation of gene expression and cytotoxic function in CD8+ T cells. J Immunol. 1992; 149(3): 949-956. [PubMed: 1353099]

7. Qin Z, Noffz G, Mohaupt M, Blankenstein T. Interleukin-10 prevents dendritic cell accumulation and vaccination with granulocyte-macrophage colony-stimulating factor gene-modified tumor cells. J Immunol. 1997; 159(2):770-776. [PubMed: 9218594]

8. Marx J. Cancer immunology. Cancer's bulwark against immune attack: MDS cells. Science. 2008; 319(5860):154-156. [PubMed: 18187637]

9. Filipazzi P, Valenti R, Huber V, et al. Identification of a new subset of myeloid suppressor cells in peripheral blood of melanoma patients with modulation by a granulocyte-macrophage colonystimulation factor-based antitumor vaccine. J Clin Oncol. 2007; 25(18):2546-2553. [PubMed: 17577033] 
10. Munn DH, Sharma MD, Hou D, et al. Expression of indoleamine 2,3-dioxygenase by plasmacytoid dendritic cells in tumor-draining lymph nodes. J Clin Invest. 2004; 114(2):280-290. [PubMed: 15254595]

11. Schnurr M, Chen Q, Shin A, et al. Tumor antigen processing and presentation depend critically on dendritic cell type and the mode of antigen delivery. Blood. 2005; 105(6):2465-2472. [PubMed: 15546948]

12. Morse MA, Hobeika AC, Osada T, et al. Depletion of human regulatory T cells specifically enhances antigen-specific immune responses to cancer vaccines. Blood. 2008; 112(3):610-618. [PubMed: 18519811]

13. Kaminski MS, Kitamura K, Maloney DG, Levy R. Idiotype vaccination against murine B cell lymphoma. Inhibition of tumor immunity by free idiotype protein. J Immunol. 1987; 138(4):12891296. [PubMed: 3492546]

14. Timmerman JM, Czerwinski DK, Davis TA, et al. Idiotype-pulsed dendritic cell vaccination for Bcell lymphoma: clinical and immune responses in 35 patients. Blood. 2002; 99(5):1517-1526. [PubMed: 11861263]

15. Shankaran V, Ikeda H, Bruce AT, et al. IFN $\gamma$ and lymphocytes prevent primary tumour development and shape tumour immunogenicity. Nature. 2001; 410(6832):1107-1111. [PubMed: 11323675]

16. Smyth MJ, Thia KY, Street SE, et al. Perforin-mediated cytotoxicity is critical for surveillance of spontaneous lymphoma. J Exp Med. 2000; 192(5):755-760. [PubMed: 10974040]

17. Malyguine A, Strobl S, Zaritskaya L, Baseler M, Shafer-Weaver K. New approaches for monitoring CTL activity in clinical trials. Adv Exp Med Biol. 2007; 601:273-284. [PubMed: 17713015]

18. Nagorsen D, Servis C, Levy N, et al. Proteasomal cleavage does not determine immunogenicity of gp100-derived peptides gp100 209-217 and gp100 209-217T210M. Cancer Immunol Immunother. 2004; 53(9):817-824. [PubMed: 15133631]

19. Maecker HT, Hassler J, Payne JK, et al. Precision and linearity targets for validation of an IFN $\gamma$ ELISPOT, cytokine flow cytometry, and tetramer assay using CMV peptides. BMC Immunol. 2008; 9:9. [PubMed: 18366814]

20. Janetzki S, Panageas KS, Ben-Porat L, et al. Results and harmonization guidelines from two largescale international ELISPOT proficiency panels conducted by the Cancer Vaccine Consortium (CVC/SVI). Cancer Immunol Immunother. 2008; 57(3):303-315. [PubMed: 17721781]

21. Wolfl M, Kuball J, Ho WY, et al. Activation-induced expression of CD137 permits detection, isolation, and expansion of the full repertoire of $\mathrm{CD}^{+} \mathrm{T}$ cells responding to antigen without requiring knowledge of epitope specificities. Blood. 2007; 110(1):201-210. [PubMed: 17371945]

22. Suni MA, Maino VC, Maecker HT. Ex vivo analysis of T-cell function. Curr Opin Immunol. 2005; 17(4):434-440. [PubMed: 15950444]

23. Chahroudi A, Silvestri G, Feinberg MB. Measuring T cell-mediated cytotoxicity using fluorogenic caspase substrates. Methods. 2003; 31(2):120-126. [PubMed: 12957569]

24. Miller RA, Maloney DG, Warnke R, Levy R. Treatment of B-cell lymphoma with monoclonal antiidiotype antibody. N Engl J Med. 1982; 306(9):517-522. [PubMed: 6173751]

25. Meeker TC, Lowder J, Maloney DG, et al. A clinical trial of anti-idiotype therapy for B cell malignancy. Blood. 1985; 65(6):1349-1363. [PubMed: 3888313]

26. Brown SL, Miller RA, Levy R. Antiidiotype antibody therapy of B-cell lymphoma. Semin Oncol. 1989; 16(3):199-210. [PubMed: 2658083]

27. Houot R, Levy R. Idiotype vaccination for lymphoma: moving towards optimisation. Leuk Lymphoma. 2009; 50(1):1-2.

28. Hurvitz SA, Timmerman JM. Current status of therapeutic vaccines for non-Hodgkin's lymphoma. Curr Opin Oncol. 2005; 17(5):432-440. [PubMed: 16093791]

29. Redfern CH, Guthrie TH, Bessudo A, et al. Phase II trial of idiotype vaccination in previously treated patients with indolent non-Hodgkin's lymphoma resulting in durable clinical responses. J Clin Oncol. 2006; 24(19):3107-3112. [PubMed: 16754937] 
30. Inoges S, Rodriguez-Calvillo M, Zabalegui N, et al. Clinical benefit associated with idiotypic vaccination in patients with follicular lymphoma. J Natl Cancer Inst. 2006; 98(18):1292-1301. [PubMed: 16985248]

31. Barrios Y, Cabrera R, Yanez R, et al. Anti-idiotypic vaccination in the treatment of low-grade Bcell lymphoma. Haematologica. 2002; 87(4):400-407. [PubMed: 11940484]

32. Bendandi M, Gocke CD, Kobrin CB, et al. Complete molecular remissions induced by patientspecific vaccination plus granulocyte-monocyte colony-stimulating factor against lymphoma. Nat Med. 1999; 5(10):1171-1177. [PubMed: 10502821]

33. Hsu FJ, Caspar CB, Czerwinski D, et al. Tumor-specific idiotype vaccines in the treatment of patients with B-cell lymphoma -long-term results of a clinical trial. Blood. 1997; 89(9):3129_ 3135. [PubMed: 9129015]

34. Kwak LW, Campbell MJ, Czerwinski DK. Induction of immune responses in patients with B-cell lymphoma against the surface-immunoglobulin idiotype expressed by their tumors. N Engl J Med. 1992; 327(17):1209-1215. [PubMed: 1406793]

35. Inoges S, Lopez-Diaz de Cerio A, Zabalegui N, et al. Prolonged idiotypic vaccination against follicular lymphoma. Leuk Lymphoma. 2009; 50(1):47-53. [PubMed: 19152172]

36. Timmerman, J. A Phase II trial to evaluate the efficacy of recombinant idiotype vaccines in untreated follicular non-Hodgkin's lymphoma in the 'watch-and-wait' period; Presented at: ASCO Annual Meeting; 2002. Abstract 13

37. Betting DJ, Kafi K, Abdollahi-Fard A, Hurvitz SA, Timmerman JM. Sulfhydryl-based tumor antigen-carrier protein conjugates stimulate superior antitumor immunity against B cell lymphomas. J Immunol. 2008; 181(6):4131-4140. [PubMed: 18768870]

38. Neelapu SS, Baskar S, Gause BL, et al. Human autologous tumor-specific T-cell responses induced by liposomal delivery of a lymphoma antigen. Clin Cancer Res. 2004; 10(24):8309-8317. [PubMed: 15623607]

39. O'Mahony D, Morris JC, Quinn C, et al. A pilot study of CTLA-4 blockade after cancer vaccine failure in patients with advanced malignancy. Clin Cancer Res. 2007; 13(3):958-964. [PubMed: 17289891]

40. Neelapu SS, Kwak LW, Kobrin CB, et al. Vaccine-induced tumor-specific immunity despite severe B-cell depletion in mantle cell lymphoma. Nat Med. 2005; 11(9):986-991. [PubMed: 16116429]

41. Davis TA, Hsu FJ, Caspar CB, et al. Idiotype vaccination following ABMT can stimulate specific anti-idiotype immune responses in patients with B-cell lymphoma. Biol Blood Marrow Transplant. 2001; 7(9):517-522. [PubMed: 11669219]

42. McCormick AA, Kumagai MH, Hanley K, et al. Rapid production of specific vaccines for lymphoma by expression of the tumor-derived single-chain Fv epitopes in tobacco plants. Proc Natl Acad Sci USA. 1999; 96(2):703-708. [PubMed: 9892697]

43. McCormick AA, Reddy S, Reinl SJ, et al. Plant-produced idiotype vaccines for the treatment of non-Hodgkin's lymphoma: safety and immunogenicity in a Phase I clinical study. Proc Natl Acad Sci USA. 2008; 105(29):10131-10136. [PubMed: 18645180]

44. Kanter G, Yang J, Voloshin A, Levy S, Swartz JR, Levy R. Cell-free production of scFv fusion proteins: an efficient approach for personalized lymphoma vaccines. Blood. 2007; 109(8):33933399. [PubMed: 17164345]

45. Timmerman JM, Singh G, Hermanson G, et al. Immunogenicity of a plasmid DNA vaccine encoding chimeric idiotype in patients with B-cell lymphoma. Cancer Res. 2002; 62(20):58455852. [PubMed: 12384547]

46. Nicchitta CV. Re-evaluating the role of heat-shock protein-peptide interactions in tumour immunity. Nat Rev Immunol. 2003; 3(5):427-432. [PubMed: 12766764]

47. Wood C, Srivastava P, Bukowski R, et al. An adjuvant autologous therapeutic vaccine (HSPPC-96; vitespen) versus observation alone for patients at high risk of recurrence after nephrectomy for renal cell carcinoma: a multicentre, open-label, randomised Phase III trial. Lancet. 2008; 372(9633):145-154. [PubMed: 18602688]

48. Testori A, Richards J, Whitman E, et al. Phase III comparison of vitespen, an autologous tumorderived heat shock protein gp96 peptide complex vaccine, with physician's choice of treatment for 
stage IV melanoma: the C-100-121 Study Group. J Clin Oncol. 2008; 26(6):955-962. [PubMed: 18281670]

49. Oki Y, McLaughlin P, Fayad LE, et al. Experience with heat shock protein-peptide complex 96 vaccine therapy in patients with indolent non-Hodgkin lymphoma. Cancer. 2007; 109(1):77-83. [PubMed: 17133412]

50. Hus I, Schmitt M, Tabarkiewicz J, et al. Vaccination of B-CLL patients with autologous dendritic cells can change the frequency of leukemia antigen-specific CD8 + T cells as well as $\mathrm{CD} 4{ }^{+} \mathrm{CD} 25^{+} \mathrm{FoxP}^{+}{ }^{+}$regulatory $\mathrm{T}$ cells toward an antileukemia response. Leukemia. 2008; 22(5): 1007-1017. [PubMed: 18323802]

51. Maier T, Tun-Kyi A, Tassis A, et al. Vaccination of patients with cutaneous T-cell lymphoma using intranodal injection of autologous tumor-lysate-pulsed dendritic cells. Blood. 2003; 102(7):23382344. [PubMed: 12714511]

52. Di Nicola M, Zappasodi R, Carlostella C, et al. Vaccination with autologous tumor-loaded dendritic cells induces clinical and immunological responses in indolent B cell lymphoma patients with relapsed and measurable disease: a pilot study. Blood. 2008

53. Dessureault S, Noyes D, Lee D, et al. A Phase-I trial using a universal GM-CSF-producing and CD40L-expressing bystander cell line (GMCD40L) in the formulation of autologous tumor cellbased vaccines for cancer patients with stage IV disease. Ann Surg Oncol. 2007; 14(2):869-884. [PubMed: 17103257]

54. Dessureault S, Noyes D, Tao J, et al. Bystander-based immunotherapy for patients with mantle cell lymphoma (MCL): proof of principle. Blood. 2007; 110:4483.

55. Biagi E, Rousseau R, Yvon E, et al. Responses to human CD40 ligand/human interleukin-2 autologous cell vaccine in patients with B-cell chronic lymphocytic leukemia. Clin Cancer Res. 2005; 11(19 Pt 1):6916-6923. [PubMed: 16203783]

56. Wierda WG, Cantwell MJ, Woods SJ, Rassenti LZ, Prussak CE, Kipps TJ. CD40-ligand (CD154) gene therapy for chronic lymphocytic leukemia. Blood. 2000; 96(9):2917-2924. [PubMed: 11049967]

57. Wierda W. Membrane-Stable, Humanized CD154 gene therapy for patients with CLL. Blood. 2006; 108:2104.

58. Spaner DE, Hammond C, Mena J, Foden C, Deabreu A. A Phase I/II trial of oxidized autologous tumor vaccines during the 'watch and wait' phase of chronic lymphocytic leukemia. Cancer Immunol Immunother. 2005; 54(7):635-646. [PubMed: 15918075]

59. Li J, Song W, Czerwinski DK, et al. Lymphoma immunotherapy with CpG oligodeoxynucleotides requires TLR9 either in the host or in the tumor itself. J Immunol. 2007; 179(4):2493-2500. [PubMed: 17675511]

60. Brody JA, Czerwinski WZ, Advani D, et al. Clinical and immunologic responses to a novel in situ lymphoma vaccine maneuver: Preliminary results of a Phase II trial of intra-tumoral CpG 7909. J Clin Oncol. 2008; 26(Suppl) Abstract 3003.

61. Elpek KG, Lacelle C, Singh NP, Yolcu ES, Shirwan H. CD ${ }^{+} \mathrm{CD} 25{ }^{+}$T regulatory cells dominate multiple immune evasion mechanisms in early but not late phases of tumor development in a B cell lymphoma model. J Immunol. 2007; 178(11):6840-6848. [PubMed: 17513732]

62. Wrzesinski C, Restifo NP. Less is more: lymphodepletion followed by hematopoietic stem cell transplant augments adoptive T-cell-based anti-tumor immunotherapy. Curr Opin Immunol. 2005; 17(2):195-201. [PubMed: 15766681]

63. Dudley ME, Wunderlich JR, Robbins PF, et al. Cancer regression and autoimmunity in patients after clonal repopulation with antitumor lymphocytes. Science. 2002; 298(5594):850-854. [PubMed: 12242449]

64. Dudley ME, Wunderlich JR, Yang JC, et al. Adoptive cell transfer therapy following nonmyeloablative but lymphodepleting chemotherapy for the treatment of patients with refractory metastatic melanoma. J Clin Oncol. 2005; 23(10):2346-2357. [PubMed: 15800326]

65. Dudley ME, Yang JC, Sherry R, et al. Adoptive cell therapy for patients with metastatic melanoma: evaluation of intensive myeloablative chemoradiation preparative regimens. J Clin Oncol. 2008 
66. Abrams SI, Brahmi Z. Target cell directed NK inactivation Concomitant loss of NK and antibodydependent cellular cytotoxicity activities. J Immunol. 1988; 140(6):2090-2095. [PubMed: 3279127]

67. Mackinnon S, Papadopoulos EB, Carabasi MH, et al. Adoptive immunotherapy evaluating escalating doses of donor leukocytes for relapse of chronic myeloid leukemia after bone marrow transplantation: separation of graft-versus-leukemia responses from graft-versus-host disease. Blood. 1995; 86(4):1261-1268. [PubMed: 7632930]

68. Porter DL, Antin JH. Adoptive immunotherapy for relapsed leukemia following allogeneic bone marrow transplantation. Leuk Lymphoma. 1995; 17(3-4):191-197. [PubMed: 8580787]

69. Khouri IF, Lee MS, Romaguera J, et al. Allogeneic hematopoietic transplantation for mantle-cell lymphoma: molecular remissions and evidence of graft-versus-malignancy. Ann Oncol. 1999; 10(11):1293-1299. [PubMed: 10631455]

70. Peggs KS, Hunter A, Chopra R, et al. Clinical evidence of a graft-versus-Hodgkin's-lymphoma effect after reduced-intensity allogeneic transplantation. Lancet. 2005; 365(9475):1934-1941. [PubMed: 15936420]

71. Albertini MR, Sosman JA, Hank JA, et al. The influence of autologous lymphokine-activated killer cell infusions on the toxicity and antitumor effect of repetitive cycles of interleukin-2. Cancer. 1990; 66(12):2457-2464. [PubMed: 2249185]

72. Berdeja JG, Hess A, Lucas DM, et al. Systemic interleukin-2 and adoptive transfer of lymphokineactivated killer cells improves antibody-dependent cellular cytotoxicity in patients with relapsed Bcell lymphoma treated with rituximab. Clin Cancer Res. 2007; 13(8):2392-2399. [PubMed: 17438098]

73. Benyunes MC, Higuchi C, York A, et al. Immunotherapy with interleukin 2 with or without lymphokine-activated killer cells after autologous bone marrow transplantation for malignant lymphoma: a feasibility trial. Bone Marrow Transplant. 1995; 16(2):283-288. [PubMed: 7581149]

74. Lister J, Rybka WB, Donnenberg AD, et al. Autologous peripheral blood stem cell transplantation and adoptive immunotherapy with activated natural killer cells in the immediate posttransplant period. Clin Cancer Res. 1995; 1(6):607-614. [PubMed: 9816022]

75. Leemhuis T, Wells S, Scheffold C, Edinger M, Negrin RS. A Phase I trial of autologous cytokineinduced killer cells for the treatment of relapsed Hodgkin disease and non-Hodgkin lymphoma. Biol Blood Marrow Transplant. 2005; 11(3):181-187. [PubMed: 15744236]

76. Laport GG, Levine BL, Stadtmauer EA, et al. Adoptive transfer of costimulated T cells induces lymphocytosis in patients with relapsed/refractory non-Hodgkin lymphoma following CD34+_ selected hematopoietic cell transplantation. Blood. 2003; 102(6):2004-2013. [PubMed: 12763934]

77. Schuster S, Levine B, Nasta S, et al. Adoptive immunotherapy with autologous CD25-depleted and CD3/CD28-costimulated T-cells (ACTC) enhances numeric and functional lymphocyte recovery after cyclophosphamide-fludarabine chemotherapy in patients with low-grade follicular lymphoma. Blood. 2007; 110:126.

78. Bollard CM, Aguilar L, Straathof KC, et al. Cytotoxic T lymphocyte therapy for Epstein-Barr virus + Hodgkin's disease. J Exp Med. 2004; 200(12):1623-1633. [PubMed: 15611290]

79. Bollard CM, Gottschalk S, Leen AM, et al. Complete responses of relapsed lymphoma following genetic modification of tumorantigen presenting cells and T-lymphocyte transfer. Blood. 2007; 110(8):2838-2845. [PubMed: 17609424]

80. Clark RA, Chong BF, Mirchandani N, et al. A novel method for the isolation of skin resident T cells from normal and diseased human skin. J Invest Dermatol. 2006; 126(5):1059-1070. [PubMed: 16484986]

81. Walker RE, Bechtel CM, Natarajan V, et al. Long-term in vivo survival of receptor-modified syngeneic T cells in patients with human immunodeficiency virus infection. Blood. 2000; 96(2): 467-474. [PubMed: 10887107]

82. Wang J, Press OW, Lindgren CG, et al. Cellular immunotherapy for follicular lymphoma using genetically modified CD20-specific $\mathrm{CD}^{+}$cytotoxic T lymphocytes. Mol Ther. 2004; 9(4):577586. [PubMed: 15093188] 
83. Chen E, Press O, Jensen M. CD8 immunomagnetic selection and interleukin-15 (IL-15) facilitate the isolation of human CD8 cytotoxic T-lymphocytes (CTL) genetically engineered to express an anti-CD20 chimeric T-cell receptor (cTCR). J Clin Oncol. 2004; 22(Suppl. 14):2542, 2004.

84. Park JR, Digiusto DL, Slovak M, et al. Adoptive transfer of chimeric antigen receptor re-directed cytolytic T lymphocyte clones in patients with neuroblastoma. Mol Ther. 2007; 15(4):825-833. [PubMed: 17299405]

85. Till BG, Jensen MC, Wang J, et al. Adoptive immunotherapy for indolent non-Hodgkin lymphoma and mantle cell lymphoma using genetically modified autologous CD20-specific T cells. Blood. 2008; 112(6):2261-2271. [PubMed: 18509084]

86. Brentjens R, Hollyman D, Weiss M, et al. A Phase I trial for the treatment of purine analogrefractory chronic lymphocytic leukemia using autologous $\mathrm{T}$ cells genetically targeted to the B cell specific antigen CD19. J Clin Oncol. 2008; 26(Suppl) Abstract 3045.

87. Cooper LJ, Ausubel L, Gutierrez M, et al. Manufacturing of gene-modified cytotoxic T lymphocytes for autologous cellular therapy for lymphoma. Cytotherapy. 2006; 8(2):105-117. [PubMed: 16698684]

88. Lamers CH, van Elzakker P, Langeveld SC, Sleijfer S, Gratama JW. Process validation and clinical evaluation of a protocol to generate gene-modified T lymphocytes for imunogene therapy for metastatic renal cell carcinoma: GMP-controlled transduction and expansion of patient's T lymphocytes using a carboxy anhydrase IX-specific scFv transgene. Cytotherapy. 2006; 8(6):542553. [PubMed: 17148030]

89. Kahlon KS, Brown C, Cooper LJ, Raubitschek A, Forman SJ, Jensen MC. Specific recognition and killing of glioblastoma multiforme by interleukin13-zetakine redirected cytolytic T cells. Cancer Res. 2004; 64(24):9160-9166. [PubMed: 15604287]

90. Bargou R, Leo E, Zugmaier G, et al. Tumor regression in cancer patients by very low doses of a T cell-engaging antibody. Science. 2008; 321(5891):974-977. [PubMed: 18703743]

91. Brentjens RJ, Santos E, Nikhamin Y, et al. Genetically targeted T cells eradicate systemic acute lymphoblastic leukemia xenografts. Clin Cancer Res. 2007; 13(18 Pt 1):5426-5435. [PubMed: 17855649]

92. Friedmann-Morvinski D, Bendavid A, Waks T, Schindler D, Eshhar Z. Redirected primary T cells harboring a chimeric receptor require costimulation for their antigen-specific activation. Blood. 2005; 105(8):3087-3093. [PubMed: 15626734]

93. Jensen M, Popplewell L, DiGiusto D, et al. A first-in-human clinical trial of adoptive therapy using CD19-specific chimeric antigen receptor re-directed T cells for recurrent/refractory follicular lymphoma. Blood. 2007; 110:288.

94. Imai C, Mihara K, Andreansky M, et al. Chimeric receptors with 4-1BB signaling capacity provoke potent cytotoxicity against acute lymphoblastic leukemia. Leukemia. 2004; 18(4):676-684. [PubMed: 14961035]

95. Zhang H, Snyder KM, Suhoski MM, et al. 4-1BB is superior to CD28 costimulation for generating $\mathrm{CD}^{+}$cytotoxic lymphocytes for adoptive immunotherapy. J Immunol. 2007; 179(7):4910-4918. [PubMed: 17878391]

96. Pule MA, Savoldo B, Myers GD, et al. Virus-specific T cells engineered to coexpress tumorspecific receptors: persistence and antitumor activity in individuals with neuroblastoma. Nat Med. 2008; 14(11):1264-1270. [PubMed: 18978797]

97. Berger C, Jensen MC, Lansdorp PM, et al. Adoptive transfer of effector CD8 ${ }^{+} \mathrm{T}$ cells derived from central memory cells establishes persistent T cell memory in primates. J Clin Invest. 2008; 118(1):294-305. [PubMed: 18060041]

98. Riddell SR, Elliott M, Lewinsohn DA, et al. T-cell mediated rejection of gene-modified HIVspecific cytotoxic T lymphocytes in HIV-infected patients. Nat Med. 1996; 2(2):216-223. [PubMed: 8574968]

99. Berger C, Flowers ME, Warren EH, Riddell SR. Analysis of transgene-specific immune responses that limit the in vivo persistence of adoptively transferred HSV-TK-modified donor T cells after allogeneic hematopoietic cell transplantation. Blood. 2006; 107(6):2294-2302. [PubMed: 16282341] 
100. Hata A, Asanuma H, Rinki M, et al. Use of an inactivated varicella vaccine in recipients of hematopoietic-cell transplants. N Engl J Med. 2002; 347(1):26-34. [PubMed: 12097537]

101. Antin JH, Guinan EC, Avigan D, et al. Protective antibody responses to pneumococcal conjugate vaccine after autologous hematopoietic stem cell transplantation. Biol Blood Marrow Transplant. 2005; 11(3):213-222. [PubMed: 15744240]

102. Rapoport AP, Stadtmauer EA, Aqui N, et al. Restoration of immunity in lymphopenic individuals with cancer by vaccination and adoptive T-cell transfer. Nat Med. 2005; 11(11):1230-1237. [PubMed: 16227990]

103. Borrello I, Sotomayor EM, Rattis FM, Cooke SK, Gu L, Levitsky HI. Sustaining the graft-versustumor effect through posttransplant immunization with granulocyte-macrophage colonystimulating factor (GM-CSF)-producing tumor vaccines. Blood. 2000; 95(10):3011-3019. [PubMed: 10807763]

104. Kochenderfer JN, Simpson JL, Chien CD, Gress RE. Vaccination regimens incorporating CpGcontaining oligodeoxynucleotides and IL-2 generate antigen-specific antitumor immunity from Tcell populations undergoing homeostatic peripheral expansion after BMT. Blood. 2007; 110(1): 450-460. [PubMed: 17371943]

105. Gattinoni L, Finkelstein SE, Klebanoff CA, et al. Removal of homeostatic cytokine sinks by lymphodepletion enhances the efficacy of adoptively transferred tumor-specific $\mathrm{CD}^{+} \mathrm{T}$ cells. J Exp Med. 2005; 202(7):907-912. [PubMed: 16203864]

106. Brody JD, Goldstein MJ, Czerwinski DK, Levy R. Immunotransplantation preferentially expands T-effector cells over T-regulatory cells and cures large lymphoma tumors. Blood. 2009; 113(1): 85-94. [PubMed: 18812472]

107. Cho HI, Hong YS, Lee MA, et al. Adoptive transfer of Epstein-Barr virus-specific cytotoxic Tlymphocytes for the treatment of angiocentric lymphomas. Int J Hematol. 2006; 83(1):66-73. [PubMed: 16443556] 


\section{Executive summary}

\section{Lymphoma-vaccine clinical-trial design considerations}

- $\quad$ Preclinical and clinical data suggest that vaccination during a high tumor burden state will be less effective. It is likely that vaccines will ultimately find their greatest use in the minimal residual disease (MRD) setting.

- $\quad$ Since standard response criteria cannot be used during MRD, immunemonitoring assays need to be developed and clinically validated as surrogate end points so that vaccine regimens can be optimized before large, randomized trials are performed to prove their efficacy.

\section{Protein versus cell-based vaccines}

- $\quad$ Protein vaccines, such as tumor-specific idiotype, are extremely specific and conceptually elegant; however, two randomized trials have been unable to demonstrate their efficacy. The final results of a third trial are pending.

- $\quad$ Cell-based vaccines using both tumor-loaded dendritic cells and in situproduced vaccines have demonstrated some efficacy in early-phase trials, even in high tumor burden patients. These should be expanded and hopefully their practicality compared with prior approaches will expedite these trials.

\section{Adoptive cell-transfer trials}

- Transfer of nonspecific effector cells such as lymphokine-activated killer cells, cytokine-induced killer cells and CD3/CD28-activated bulk peripheral blood lymphocytes have not shown clear single-agent activity, but have demonstrated the importance of certain T-cell signals (such as costimulation) in allowing persistence of transferred cells.

- $\quad$ Transfer of effector T cells specific for known lymphoma antigens (such as Epstein-Barr virus antigens) has demonstrated remarkable single-agent activity, although it is not clear if such antigens can be identified for the most common lymphoma subtypes.

- Transfer of effector cells genetically engineered to recognize antigens of common lymphoma subtypes is feasible and early-phase trials are ongoing.

\section{Immunotransplant}

- Immunotransplant will be able to combine the breadth of a lymphoma vaccine-induced immune response and the advantages of adoptive cell transfer (such as the opportunity to lymphodeplete patients to remove suppressive immune elements). This approach has demonstrated efficacy preclinically and early-phase trials are ongoing. 


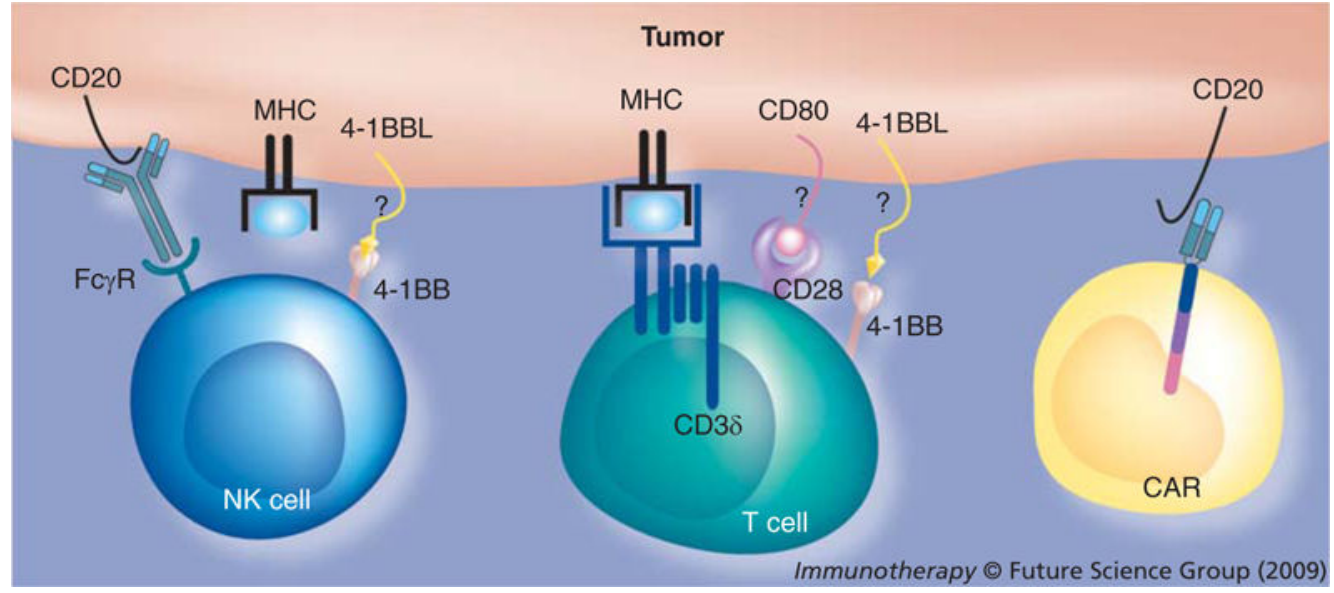

Figure 1. CAR-transduced effector cells receive 'guaranteed' costimulaotry signals on recognition of target cells, which may not otherwise provide them

CAR: Chimeric-antigen receptor. 


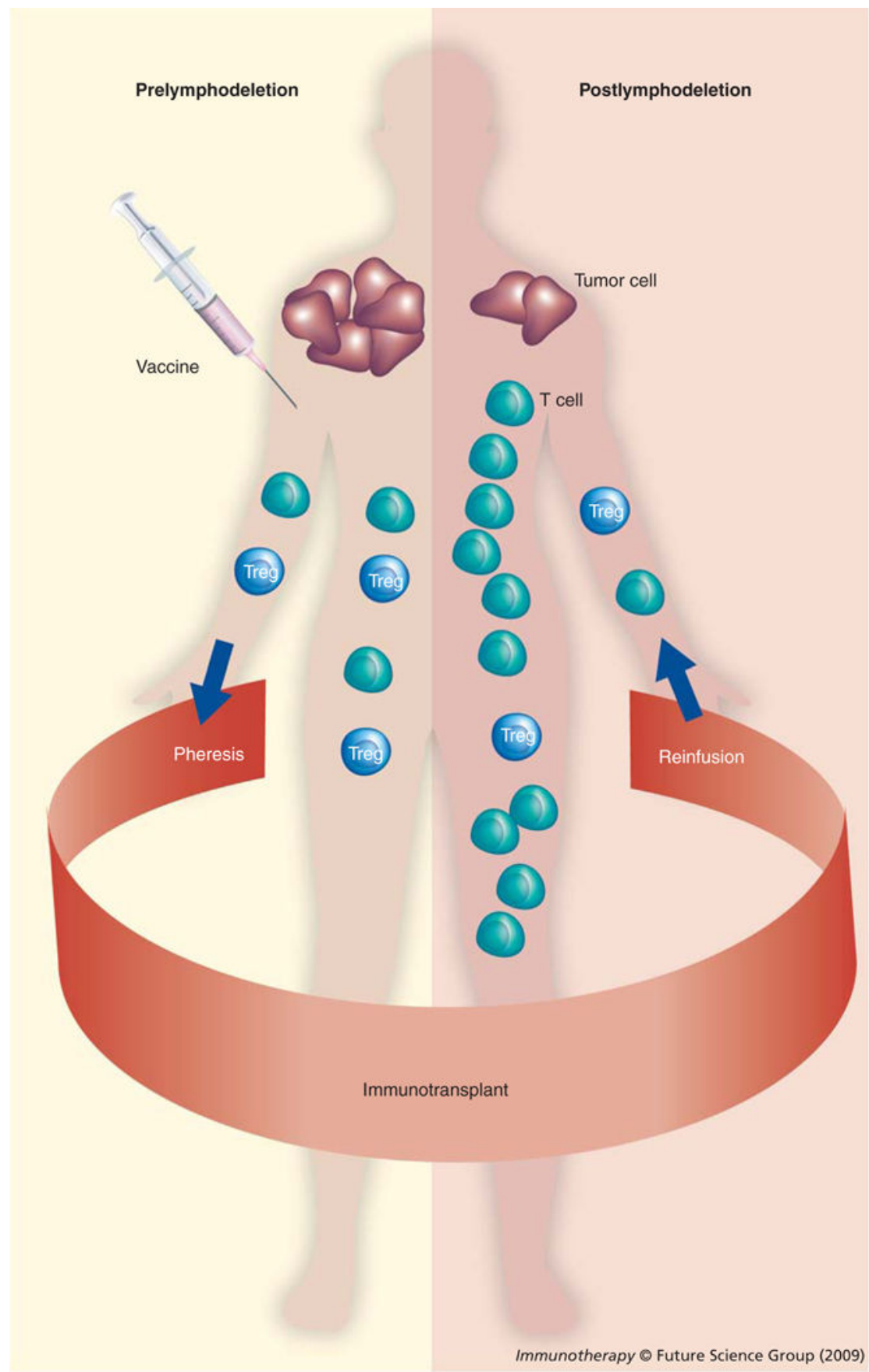

Figure 2.

Immunotransplant induces selective proliferation of antitumor T cells. 


\section{Table 1}

Phase III trials of Id-KLH vaccination for indolent lymphoma.

\begin{tabular}{|c|c|c|c|}
\hline & Genitope & Favrille & Biovest \\
\hline Randomized patients & 287 & 349 & 111 \\
\hline Prevaccination therapy & CVP & Rituxan ${ }^{\circledR}$ & PACE (RCHOP in 10\%) \\
\hline$\%$ of treated patients in $\mathrm{CR}+\mathrm{CRu}$ & $\sim 10 \%$ & $8^{*}$ & 100 \\
\hline Primary end point (Id-KLH vs control; months) & $\begin{array}{l}\text { PFS } 19.1 \text { vs } 23.3 ; p= \\
0.2971\end{array}$ & TTP $p>0.05$ & $\begin{array}{l}\text { DFS } 44.2 \text { vs } 30.6 ; p= \\
0.045\end{array}$ \\
\hline Immune response $(\%)$ & 40.5 (humoral) & NA & NA \\
\hline $\begin{array}{l}\% \text { of patients with 'late' clinical response (Id-KLH vs } \\
\text { control) }\end{array}$ & 16.1 vs 20 & $\begin{array}{l}41 \text { (blinded; ASH } \\
\text { 2006] }\end{array}$ & NA \\
\hline
\end{tabular}

CRu not separately reported.

ASH: Ameican Society of Hematology; CR: Complete response; CRu: Complete response, unconfirmed; CVP: Cyclophosphamide, vincristine and prednisone; DFS: Disease-free survival; Id-KLH: Idiotype-keyhole limpet hemocyanin; NA: Not applicable; PACE: Preoperative Assessment of Cancer in the Elderly;

PFS: Progression-free survival; RCHOP: Rituximab, cyclophosphamide, doxorubicin, vincristine and prednisolone; TTP: Time to progression. 
Table 2

Clinical trials of cell-based lymphoma vaccines.

\begin{tabular}{|c|c|c|c|c|}
\hline & Patients (n) & Vaccine & Responses (immune and clinical) & Ref. \\
\hline $\begin{array}{l}\text { Desserault et al. } \\
\text { (2007) }\end{array}$ & 22 & $\begin{array}{l}5-15 \times 10^{6} \text { irradiated MCL cells admixed with } \\
5-15 \times 10^{6} \mathrm{GM}-\mathrm{CSF} / \mathrm{CD} 154-\text { expressing cells }\end{array}$ & $\begin{array}{l}\text { No IR reported; one molecular } \\
\text { response }\end{array}$ & {$[53,54]$} \\
\hline Biagi et al. (2005) & 9 & CD154-transfected CLL cells & $\begin{array}{l}\text { Seven T-cell responses; three PR } \\
\text { (transient) }\end{array}$ & [55] \\
\hline Wierda et al. (2006) & 11 & $3-30 \times 10^{8} \mathrm{CD} 154$-expressing CLL cells & $\begin{array}{l}\text { Three of three T-cell responses; } \\
\text { transient LN and PBL responses }\end{array}$ & [57] \\
\hline Spaner et al. (2005) & 18 & $1-10 \times 10^{8}$ heat-shocked, oxidized CLL cells & $\begin{array}{l}13 \text { minor, three robust } \mathrm{T} \text {-cell responses } \\
\text { (c/w clinical responses); five of } 18 \mathrm{PR} \\
\text { (transient) }\end{array}$ & [58] \\
\hline Hus et al. (2008) & 12 & $5-13 \times 10^{6}$ DCs pulsed with CLL lysate & $\begin{array}{l}\text { IR data indeterminate; five minor } \\
\text { responses }\end{array}$ & [50] \\
\hline Maier et al. (2003) & 10 & $1 \times 10^{6}$ DCs pulsed with CTCL lysate & $\begin{array}{l}\text { Eight of eight } \mathrm{DTH}^{+}, 3 / 5 \mathrm{~T} \text {-cell } \\
\text { proliferation an IFN- } \gamma^{+} \text {; one } \mathrm{CR} \text {, four } \\
\text { PR }\end{array}$ & [51] \\
\hline Di Nicola et al. (2008) & 18 & DCs pulsed with heat-shocked B-NHL & $\begin{array}{l}\text { Two of three IFN- } \gamma^{+} \text {and CCR7; three } \\
\text { CR, three PR }\end{array}$ & [52] \\
\hline Brody et al. (2008) & 15 & Intratumoral $\mathrm{CpG}$ & IR data pending; one CR, two PR & [60] \\
\hline
\end{tabular}

B-NHL: B-cell non-Hodgkin lymphoma; CLL: Chronic lymphocytic leukemia; CR: Complete response; CTCL: Cutaneous T-cell lymphoma; c/w: Compared with; DC: Dendritic cell; DTH: Delayed-type hypersensitivity; IR: Intermediate response; LN: Lymph node; MCL: Mast-cell like; PBL: Peripheral blood lymphocyte; PR: Partial response. 


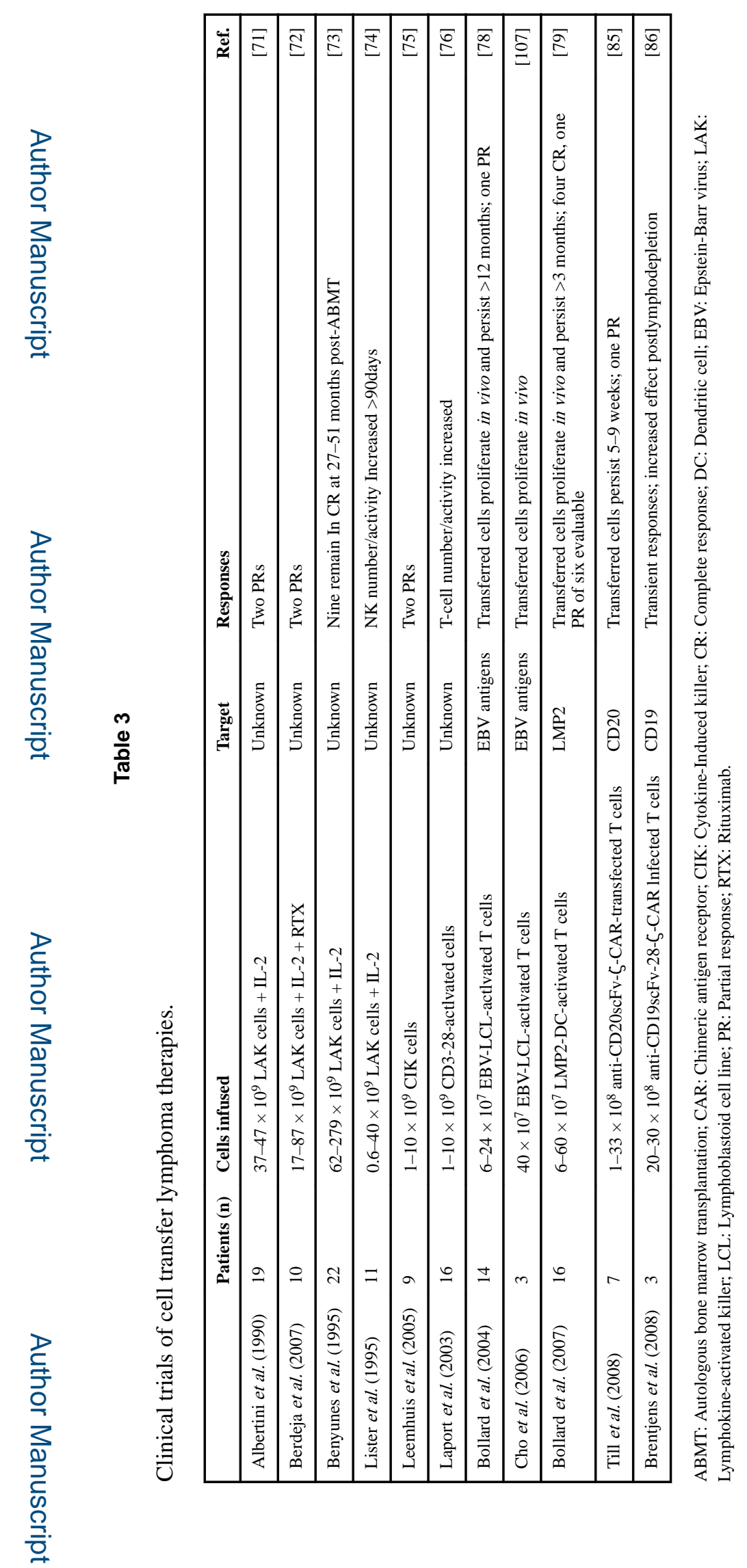

Immunotherapy. Author manuscript; available in PMC 2017 June 13. 